\title{
Meat Unwinding Techniques in Kilishi Processing in North Cameroon: Constraints and Innovations
}

\author{
Aimé Christian NDIH ${ }^{1, *}$, Robert NDJOUENKEU ${ }^{2}$, François Xavier ETOA ${ }^{3}$ \\ ${ }^{1}$ Department of Agriculture, Livestocks and By Products, National Advanced School of Engineering, \\ University of Maroua, P.O.Box 46 Maroua, Cameroon \\ ${ }^{2}$ Department of Food Science and Nutrition, National School Of Agro-Industrial Sciences, P.O.Box 455 Ngaoundere, Cameroon \\ ${ }^{3}$ Department of Microbiology, University of Yaoundé I, P.O.Box 337 Yaoundé, Cameroon \\ *Corresponding author: ndihac@yahoo.fr
}

\begin{abstract}
Slicing and low technological quality of meat constitute the major technological constraints of kilishi manufacturing process (slices of meat, dried or smoked, seasoned with a cocktail of ingredients and grilled or not on firewood). The unwinding process remains painful and requires skill coupled with proven dexterity in its production. It was to minimize these constraints that a comparative study of three unwinding modes: along the muscle, the $15 \mathrm{~cm} \times 5 \mathrm{~cm} \times 5 \mathrm{~cm}$ and the successive rolling (innovative method) was conducted to know the best unwinding method on two muscles from a zebu goudali, male, brown dress and aged four years,: Round and thick rib on five steps aging period (rigor-mortis, 24h, 48h, 72h and 96h). The results obtained, showed that meat from the slaughterhouse reached the level of the kilishi units in Maroua-Cameroun after 199 $\pm 8.4 \mathrm{~min}$ in rigor-mortis state and it deserved to be aging at least 24h to improve its firmness and from $48 \mathrm{~h}$ to facilitate unwinding. The unwinding techniques were significantly different $(\mathrm{p} \leq 0.05)$ and successive rolling appeared as the best unwinding mode which reduced the unwinding time of $500 \mathrm{~g}$ of meat from $15.61 \pm 0.57 \mathrm{~min}$ to $5.88 \pm 0.2 \mathrm{~min}$ for round and $14.85 \pm 0.65 \mathrm{~min}$ at $5.58 \pm$ $0.21 \mathrm{~min}$ for thick rib during rigor mortis. These times failed after $96 \mathrm{~h}$ of aging at $4 \pm 2^{\circ} \mathrm{C}$ at $3.16 \pm 0.15 \mathrm{~min}$ for the Round at $2.48 \pm 0.38$ min for Thick rib. Aging alone and / or combined with successive rolling improved the firmness of the meat and significantly reduced the unwinding time. The successive rolling feet for all types of muscles joined, with aging contributed to increase the number of muscles of the carcass that had to be used in the processing of kilishi.
\end{abstract}

Keywords: kilishi, technological quality, unwinding and aging

Cite This Article: Aimé Christian NDIH, Robert NDJOUENKEU, and François Xavier ETOA, "Meat Unwinding Techniques in Kilishi Processing in North Cameroon: Constraints and Innovations." American Journal of Food Science and Technology, vol. 6, no. 5 (2018): 204-208. doi: 10.12691/ajfst-6-5-2.

\section{Introduction}

North-Cameroon is the main area of livestock and artisanal processing of meat by secular techniques as drying, roasting and smoking. Among the products resulting from these techniques, is kilishi (dried or smoked slices of meat, seasoned with a cocktail of ingredients either roasted or not on firewood).

It stands out for its cultural value and its potential values is estimated at 8 billion FCFA [1]. Manufacturing processes of kilishi are still artisanal, practiced by actors operating in the informal sector and whose erratic nature of processing cannot guarantee the safety of products, nor meet the requirements of consumers who have become more rigorous of quality. Unwinding meat consists in slicing meat which is one of the major technological constraints of the process, because it is very painful and requires a lot of skill coupled with a proven dexterity, [2].

This operation slows down the process and exposes the actor to multiple wounds and the raw material to various contaminations. This delicate operation will later give, seize, name, geographical area of production and presentation of the kilishi. This study was conducted to reduce the hardness of unwinding.

\section{Materials and Methods}

\subsection{Biological Material}

Two muscles, the thick rib (front quarter muscle) and the round (hindquarter muscle) from a zebu goudali, which was 4 years old, male in a brown dress, were bought at the market in the neighborhood of Dougoï in the town of Maroua-Cameroon from a producer selected according to the criteria of attendancy, quantity of meat sold per day and his knowledge of categorical cutting.

\subsection{Methods}

\subsubsection{Sampling, Packaging and Transport}

Samples of muscle were collected at a rate of 22500 g per zebu goudali. The samples were preserved in pre-sterile polyethylene bags, transported to the laboratory 
in a cooler containing ice-cream loaf to prevent meat spoilage.

Each muscle was divided into five batches: the first batch was unwound directly at the rigor-mortis state. The other muscles were stored at $4^{\circ} \mathrm{C} \pm 2$ for aging and sampled after 24h, $48 \mathrm{~h}, 72 \mathrm{~h}$ and $96 \mathrm{~h}$ respectively for unwinding.

\subsubsection{Timekeeping of Unit Operations}

The Techno L8 was used for Timekeeping.

\subsubsection{Weight}

The Philips HR 2385 0.1g precision scale was used for weighing.

\subsubsection{Determination of $\mathbf{p H}$}

The $\mathrm{pH}$ values were made according to the method [3].

\subsection{Statistical Analysis}

The values of the various parameters evaluated are the averages of three repetitions $(n=3)$ and the responses were represented by the means \pm standard deviations. Analysis of the variance (ANOVA) was performed using the STATGRAPHICS Plus 5.0 software on the responses. The significant differences between their values were determined at the $5 \%$ probability level.

\section{Results and Discussion}

The results in Table 1 help to estimate the time required to supply meat to the various kilishi production plants in Maroua (199 $\pm 8.4 \mathrm{~min})$ and showed that the main meat used was in rigor-mortis state. The $\mathrm{pH}$ values $(6.55 \pm 0.07)$ are below the ultimate $\mathrm{pH}$, which indicated that the meat provided did not undergo aging.

\subsection{Providing of Meat}

Table 1. Duration of meat production and some technological parameters

\begin{tabular}{|c|c|c|c|}
\hline Unit operations & Time (min) & $\mathrm{T}\left({ }^{\circ} \mathrm{C}\right)$ & pH \\
\hline VS I Ante-mortem & $12.6 \pm 2.38$ & & \\
\hline $\begin{array}{l}\text { Neutralization and } \\
\text { slaughtering }\end{array}$ & $16.2 \pm 1.5$ & & \\
\hline Bleeding & $12.8 \pm 1.9$ & & \\
\hline Skining & $9.0 \pm 1.6$ & & \\
\hline Eviscerating & $12.8 \pm 1.9$ & & \\
\hline Dorsal slot & $12.4 \pm 1.80$ & & \\
\hline Washing & $11.2 \pm 1.30$ & & \\
\hline VSI post-mortem & $15.8 \pm 0.8$ & & \\
\hline Cutting in quarters & $5.2 \pm 1.09$ & & \\
\hline Business and transactions & $34 \pm 4.1$ & & \\
\hline Purchase by the producer & $12 \pm 2.12$ & & \\
\hline $\begin{array}{l}\text { Removal and transport to the } \\
\text { butcher }\end{array}$ & $32.4 \pm 2.3$ & & \\
\hline Transport to kilishi unit & $12.6 \pm 1.9$ & & \\
\hline $\begin{array}{l}\text { Arrival of the meat in the } \\
\text { unit }\end{array}$ & $199 \pm 8.4$ & & \\
\hline $\begin{array}{l}\text { Temperature in the heart of } \\
\text { the meat }\end{array}$ & & $32 \pm 1.3$ & \\
\hline $\begin{array}{l}\mathrm{pH} \text { of the meat at the } \\
\text { beginning of the trimming }\end{array}$ & & & $6.55 \pm 0.07$ \\
\hline
\end{tabular}

\section{2. pH Values}

The $\mathrm{pH}$ and temperature showed the evolution of meat tenderness, according to [4], which indicated that the rate of drop of a muscle's $\mathrm{pH}$ also determines its tenderness level. Initial and global tenderness were not very different between breeds and the tenderness of one muscle was not related to another muscle of the same carcass. These times and $\mathrm{pH}$ allowed to say that muscles used for the processing of kilishi did not reach the tenderness because of the $\mathrm{pH} 6.55$ inferior to the ultimate $\mathrm{pH}$ of 5.5 . According to [5], the evolution of post-mortem tenderness depends on the type and proportion of fiber. Meats can have the same $\mathrm{pH}$ after a specific time, but those with a low $\mathrm{pH}$ drop were softer. The $\mathrm{pH}$ of the muscles obtained 3 hours after slaughter accounted for 52\% of the tenderness variability. It was proposed by [6] that the $\mathrm{pH}$ at 3 hours would be an indicator of tenderness and that at a $\mathrm{pH}$ of about 6.1 , the meat would be softer. These results of $\mathrm{pH}$ highlighted the fact that meat to be used for kilishi production deserved further aging to facilitate unwinding. The level of meat tenderness at the kilishi scale would be insufficient according to what reported [7] on postmortem $\mathrm{pH}$ of the meat. Some producers' behaviors corroborated the fact, because some add vinegar or lemon to the meat to speed up firmness and tenderness after trimming.

\subsection{The Trimming}

After trimming, the mass of waste varies from 5 to $30 \%$ of the initial mass of meat, which is substantially similar to the 7 to $26 \%$ of [8]. The amount of waste here was function of the nature of the muscle, its location and its constitution in connective tissue. The muscles of the forequarter have very high amounts of connective tissue compare to the muscles in the hindquarter (Figure 1).

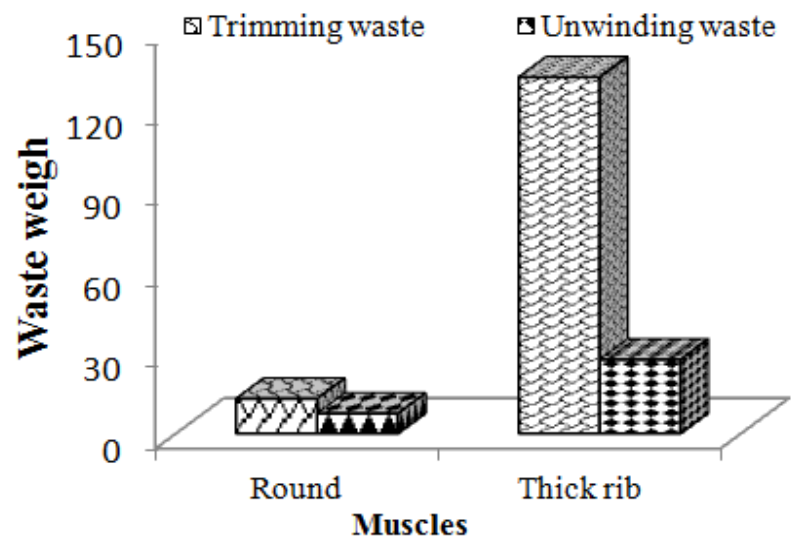

Figure 1. Profile of trimming waste of round and thick rib

\subsection{The Duration of the Unwinding}

The comparative study of three types of unwinding (along the muscle, the $15 \times 5 \times 5 \mathrm{~cm}$ and the successive rolling) were shown in Tables 2 and 3. The durations of unwinding were proportional to the type of muscle, the weight and the state of aging. These results corroborated those obtained by [9]. Which estimated it between 25 to 38 min per $\mathrm{kg}$ of fresh meat rolled out. Although the 
results showed that regardless of the condition or weight of the muscle, the successive rolling has a significantly $(p<0.05)$ unwinding time less than the two others. Nevertheless, improvements were still needed to refine and popularize this technique.

From Figure 2, what emerged, was that the duration of unwinding decreases as the meat was aging.

The rigor-mortis state has the highest unwinding time simply because, at that state, the hardness of the meat was at its highest point. From studies of myofibrillar structure in contrast microscopy phase or electron microscopy, Penny [10] and Ouali [11] have noticed several modifications such as transverse fragmentation of myofibrils; which could explain this ease in unwinding. During rigor-mortis, the muscle is hard and the fibers in full contraction do not facilitate unwinding except in the case of a mechanical tenderizing where the fibers are cut and do not lend themselves to unwinding.

Table 2 and Table 3 compared the three types of unwinding (along the muscle, the $15 \times 5 \times 5 \mathrm{~cm}$ and the successive rolling) on two muscles the round and the thick rib to identify the best unwinding method. These tables have shown the influence of aging on the reduction of the hardness of the unwinding and the successive rolling appeared to be significantly different $(p<0.05)$ from the others techniques mentioned above. From the same tables, it appeared significantly that the aging of the meat had an influence in each unwinding mode. This confirmed the work of Taylor [12] which showed that after aging of 24 hours, proteasomes induced fragilizations at the level of the streak $\mathrm{Z}$ and bands $\mathrm{A}$ and $\mathrm{I}$. In the same vein,
CIV [13] stated that for carcasses properly chilled to a temperature of $7^{\circ} \mathrm{C}$ or lower, aging begins within 24 to 48 hours after slaughter. In order to obtain a good firmness and an ease in unwinding, it was necessary to age the meat intended for the kilishi manufacture. In rigor-mortis, the muscle is hard, which makes unwinding difficult and requires a very sharp knife, increasing the risk of scarification and might cease the work. The aged muscle begins to soften and becomes firm, which positively influences the unwinding time and kilishi production time as well.

\subsection{The Unwinding along the Muscle}

The unwinding along the muscle had some constraints, because some muscles used in kilishi production such as rumsteack, tender; round, etc ... have weights between 3 to $8 \mathrm{~kg}$ and a length between $27 \mathrm{~cm}$ and $50 \mathrm{~cm}$ depending on the gabaris of the carcasses; which make the unwinding and the handling difficult.

This mode will increase the working time, because it is not fast enough at a given moment and it leads and lead to scarifications. The marketing aspect was not left behind; its presentation on trays was subject to various contaminations. In addition to the deficiencies noted above, the fingers of the actors are scarified on almost all phalanges, proof that even the dexterity of the unwinder was not enough to avoid scarifications.

The unwinding along the muscle is better on muscles whose thickness was between $5 \mathrm{~cm}$ and $7 \mathrm{~cm}$ and length between $13 \mathrm{~cm}$ and $25 \mathrm{~cm}$.

Table 2. Comparative study of unwinding methods of meat against aging times

\begin{tabular}{|c|c|c|c|c|c|c|}
\hline \multirow[b]{3}{*}{ Settings } & \multicolumn{2}{|c|}{ Along the muscle } & \multicolumn{2}{|c|}{$15 \mathrm{~cm} \times 5 \mathrm{~cm} \times 5 \mathrm{~cm}$} & \multicolumn{2}{|c|}{ Successive rolling } \\
\hline & $\begin{array}{l}\text { Muscle back } \\
\text { Round }\end{array}$ & $\begin{array}{c}\text { Muscle front } \\
\text { Thick rib }\end{array}$ & $\begin{array}{c}\text { Muscle back } \\
\text { Round }\end{array}$ & $\begin{array}{c}\text { Muscle front } \\
\text { Thick rib }\end{array}$ & $\begin{array}{c}\text { Muscle back } \\
\text { Round }\end{array}$ & $\begin{array}{c}\text { Muscle front } \\
\text { Thick rib }\end{array}$ \\
\hline & \multicolumn{6}{|c|}{ Rigor-mortis } \\
\hline Weight of waste from unwinding (g) & $7.5 \pm 2.12^{\mathrm{b}}$ & $27.5 \pm 3.53^{\mathrm{c}}$ & $1,5 \pm 0,7^{\mathrm{a}}$ & $1,7 \pm 0,41^{\text {a }}$ & $1,5 \pm 0,7^{\mathrm{a}}$ & $3 \pm 1,41^{\mathrm{a}}$ \\
\hline Unwinding time (min) & $15.61 \pm 0.57^{c}$ & $14.80 \pm 0.36^{\mathrm{bc}}$ & $14.51 \pm 0.78^{b}$ & $14.85 \pm 0.65^{\mathrm{bc}}$ & $5.88 \pm 0.2^{\mathrm{a}}$ & $5.58 \pm 0.21^{\mathrm{a}}$ \\
\hline Thickness muscle rolls (cm) & $1.5 \pm 0.5^{\mathrm{a}}$ & $1.5 \pm 0.53^{\mathrm{a}}$ & $1.25 \pm 0.07^{\mathrm{a}}$ & $1.95 \pm 0.14^{\mathrm{b}}$ & $1.98 \pm 0.44^{\mathrm{ab}}$ & $1.93 \pm 0.09^{b}$ \\
\hline \multirow[t]{2}{*}{ Brine penetration time (min) } & $27 \pm 2^{\mathrm{b}}$ & $21 \pm 8^{\mathrm{a}}$ & $25 \pm 3^{\mathrm{ab}}$ & $27 \pm 7^{\text {ab }}$ & $45 \pm 1.9^{c}$ & $32 \pm 1.5 b$ \\
\hline & \multicolumn{6}{|c|}{ 24h post-mortem } \\
\hline Weight of waste from unwinding (g) & $5 \pm 1.07^{\mathrm{a}}$ & $22 \pm 4.24^{\mathrm{c}}$ & $3.5 \pm 1.12^{\mathrm{a}}$ & $12 \pm 2.82^{\mathrm{b}}$ & $1.5 \pm 0.12^{\mathrm{a}}$ & $1.4 \pm 0.41^{\mathrm{a}}$ \\
\hline Unwinding time (min) & $6.18 \pm 0.48^{\mathrm{c}}$ & $6.18 \pm 0.24^{\mathrm{c}}$ & $8.35 \pm 0.75^{d}$ & $6.75 \pm 0.61^{\mathrm{c}}$ & $3.25 \pm 0.21^{\mathrm{a}}$ & $5.08 \pm 0.23^{b}$ \\
\hline Thickness muscle rolls (cm) & $1.1 \pm 0.17^{\mathrm{a}}$ & $1.37 \pm 0.14^{\mathrm{b}}$ & $1.32 \pm 0.03^{b}$ & $1.41 \pm 0.02^{\mathrm{bc}}$ & $1.8 \pm 0.1^{\mathrm{d}}$ & $1.68 \pm 0.18^{\mathrm{cd}}$ \\
\hline \multirow[t]{2}{*}{ Brine penetration time (min) } & $15 \pm 1.9^{\mathrm{a}}$ & $20 \pm 1.5^{b}$ & $30 \pm 1.4^{c}$ & $28 \pm 1.5^{c}$ & $58 \pm 1.8^{\mathrm{e}}$ & $51 \pm 1.4^{\mathrm{d}}$ \\
\hline & \multicolumn{6}{|c|}{ 48h post-mortem } \\
\hline Weight of waste from unwinding (g) & $3 \pm 1.24^{\mathrm{a}}$ & $31 \pm 8.45^{\mathrm{b}}$ & $4.5 \pm 1.36^{\mathrm{a}}$ & $5.5 \pm 1.53^{\mathrm{a}}$ & $2.5 \pm 0.7^{\mathrm{a}}$ & $7 \pm 1.0^{\mathrm{a}}$ \\
\hline Unwinding time (min) & $4.9 \pm 0.6^{\mathrm{bc}}$ & $6.85 \pm 0.5^{\mathrm{d}}$ & $5.33 \pm 0.33^{\mathrm{c}}$ & $8.15 \pm 0.5^{\mathrm{e}}$ & $3.11 \pm 0.21^{\mathrm{a}}$ & $4.38 \pm 0.61^{\mathrm{b}}$ \\
\hline Thickness muscle rolls (cm) & $1.22 \pm 0.1^{\mathrm{b}}$ & $1.15 \pm 0.07^{\mathrm{b}}$ & $0.74 \pm 0.34^{\mathrm{a}}$ & $1.06 \pm 0.05^{\mathrm{b}}$ & $2.3 \pm 0.28^{\mathrm{c}}$ & $1.87 \pm 0.03^{\mathrm{c}}$ \\
\hline \multirow{2}{*}{ Brine penetration time (min) } & $17 \pm 1.2^{\mathrm{a}}$ & $25 \pm 2.7^{\mathrm{ab}}$ & $28 \pm 1.9^{\mathrm{ab}}$ & $21 \pm 1.5^{\mathrm{a}}$ & $40 \pm 13^{\mathrm{bc}}$ & $47 \pm 9^{c}$ \\
\hline & \multicolumn{6}{|c|}{ 72h post-mortem } \\
\hline Weight of waste from unwinding (g) & $4.5 \pm 0.53^{\mathrm{b}}$ & $3 \pm 0.9^{\mathrm{a}}$ & $6 \pm 1.41^{\mathrm{b}}$ & $5.5 \pm 1.12^{\mathrm{b}}$ & $2.5 \pm 0.7^{\mathrm{a}}$ & $2.7 \pm 0.8^{\mathrm{a}}$ \\
\hline Unwinding time (min) & $6.36 \pm 1.91^{\mathrm{cd}}$ & $6.78 \pm 0.41^{\mathrm{d}}$ & $4.2 \pm 0.05^{\mathrm{bc}}$ & $6 \pm 0.43^{\mathrm{d}}$ & $3.71 \pm 0.31^{\mathrm{ab}}$ & $2.45 \pm 0.41^{\mathrm{a}}$ \\
\hline Thickness muscle rolls (cm) & $1.04 \pm 0.07^{\mathrm{ab}}$ & $1.19 \pm 0.01^{\mathrm{bc}}$ & $1.08 \pm 0.12^{\mathrm{ab}}$ & $0.92 \pm 0.1^{\mathrm{a}}$ & $1.75 \pm 0.21^{\mathrm{d}}$ & $1.6 \pm 0.28^{\text {cd }}$ \\
\hline \multirow[t]{2}{*}{ Brine penetration time (min) } & $19 \pm 1.5^{\mathrm{b}}$ & $30 \pm 1.1^{\mathrm{c}}$ & $15 \pm 2^{\mathrm{a}}$ & $17 \pm 2.6^{\mathrm{ab}}$ & $44 \pm 1.7^{\mathrm{d}}$ & $32 \pm 1.1^{\mathrm{c}}$ \\
\hline & \multicolumn{6}{|c|}{ 96h post-mortem } \\
\hline Weight of waste from unwinding (g) & $4.5 \pm 0.53^{\mathrm{a}}$ & $11 \pm 4.24^{\mathrm{b}}$ & $4 \pm 1.82^{\mathrm{a}}$ & $5.5 \pm 1.53^{\mathrm{a}}$ & $4.5 \pm 0.7^{\mathrm{a}}$ & $3 \pm 0.41^{\mathrm{a}}$ \\
\hline Unwinding time (min) & $3.38 \pm 0.16^{\mathrm{bc}}$ & $5.33 \pm 0.36^{\mathrm{e}}$ & $3.75 \pm 0.25^{\mathrm{cd}}$ & $4.03 \pm 0.18^{\mathrm{c}}$ & $3.16 \pm 0.15^{\mathrm{b}}$ & $2.48 \pm 0.38^{\mathrm{a}}$ \\
\hline Thickness muscle rolls (cm) & $1.22 \pm 0.1^{\mathrm{a}}$ & $1.15 \pm 0.02^{\mathrm{a}}$ & $1.32 \pm 0.1^{\mathrm{a}}$ & $1.14 \pm 0.21^{\mathrm{a}}$ & $2.12 \pm 0.53^{\mathrm{b}}$ & $2.14 \pm 0.22^{b}$ \\
\hline Brine penetration time (min) & $25 \pm 1.4^{\mathrm{a}}$ & $29 \pm 8^{\mathrm{a}}$ & $29 \pm 4.24^{\mathrm{a}}$ & $25 \pm 3^{\mathrm{a}}$ & $57 \pm 1.6^{\mathrm{b}}$ & $71 \pm 1.5^{c}$ \\
\hline
\end{tabular}

N.B: Values with the same letters do not differ significantly at the probability threshold $(\mathrm{p}<0.05)$. 
Table 3. Evaluation of the influence of meat aging on reducing the hardness of unwinding

\begin{tabular}{|c|c|c|c|c|c|c|c|c|c|c|}
\hline \multirow{4}{*}{ Settings } & \multicolumn{10}{|c|}{ Along the muscle } \\
\hline & \multicolumn{2}{|c|}{ Rigor-mortis } & \multicolumn{2}{|c|}{ 24h post-mortem } & \multicolumn{2}{|c|}{ 48h post-mortem } & \multicolumn{2}{|c|}{ 72h post-mortem } & \multicolumn{2}{|c|}{ 96h post-mortem } \\
\hline & Muscle back & Muscle front & Muscle back & k Muscle front & Muscle back & Muscle front & t Muscle back & Muscle front & Muscle back & Muscle front \\
\hline & Round & Thick rib & Round & Thick rib & Round & Thick rib & Round & Thick rib & Round & Thick rib \\
\hline $\begin{array}{c}\text { Weight of } \\
\text { waste from } \\
\text { unwinding (g) }\end{array}$ & $7.5 \pm 2.12^{\mathrm{abc}}$ & $27.5 \pm 3.53^{\mathrm{e}}$ & $5 \pm 1.07^{\mathrm{ab}}$ & $22 \pm 4.24^{4}$ & $3 \pm 1.24^{\mathrm{a}}$ & $31 \pm 8.45^{\mathrm{e}}$ & $4.5 \pm 1.53^{\mathrm{ab}}$ & $13 \pm 1.82^{\mathrm{c}}$ & $4.5 \pm 1.53^{\mathrm{ab}}$ & $11 \pm 4.24^{\mathrm{bc}}$ \\
\hline $\begin{array}{l}\text { Unwinding } \\
\text { time (min) }\end{array}$ & $15.61 \pm 0.57^{\mathrm{f}}$ & $14.80 \pm 0.36$ & $6.18 \pm 0.48^{\text {cde }}$ & e $6.18 \pm 0.24^{\text {cde }}$ & $4.9 \pm 0.6^{\mathrm{ab}}$ & $6.85 \pm 0.5^{\mathrm{e}}$ & $6.36 \pm 1.91^{\text {bcd }}$ & $6.78 \pm 0.41^{\text {de }}$ & $3.38 \pm 0.16^{\mathrm{a}}$ & $5.33 \pm 0.36^{\mathrm{bc}}$ \\
\hline $\begin{array}{l}\text { Thickness } \\
\text { muscle rolls } \\
\text { (cm) }\end{array}$ & $1.5 \pm 0.5^{\mathrm{a}}$ & $1.5 \pm 0.53^{\mathrm{a}}$ & $1.1 \pm 0.17^{\mathrm{a}}$ & $1.37 \pm 0.14^{\mathrm{a}}$ & $1.22 \pm 0.1^{\mathrm{a}}$ & $1.15 \pm 0.07^{\mathrm{a}}$ & $1.04 \pm 0.07^{\mathrm{a}}$ & $1.19 \pm 0.01^{\mathrm{a}}$ & $1.22 \pm 0.1^{\mathrm{a}}$ & $1.15 \pm 0.02^{\mathrm{a}}$ \\
\hline $\begin{array}{c}\text { Brine } \\
\text { penetration } \\
\text { time (min) }\end{array}$ & $27 \pm 2^{\text {de }}$ & $21 \pm 8^{\mathrm{abc}}$ & $15 \pm 1.9^{\mathrm{a}}$ & $20 \pm 1.5^{\text {abcd }}$ & $17 \pm 1.2^{\mathrm{ab}}$ & $25 \pm 2.7^{\text {bcde }}$ & $19 \pm 1.5^{\mathrm{abcd}}$ & $30 \pm 1.1^{\mathrm{e}}$ & $25 \pm 1.4^{\mathrm{abcd}}$ & $29 \pm 8^{\text {cde }}$ \\
\hline & \multicolumn{10}{|c|}{$15 \mathrm{~cm} \times 5 \mathrm{~cm} \times 5 \mathrm{~cm}$} \\
\hline $\begin{array}{c}\text { Weight of } \\
\text { waste from } \\
\text { unwinding (g) }\end{array}$ & $0.5 \pm 0.7^{\mathrm{a}}$ & $1 \pm 0.41^{\mathrm{ab}}$ & $3.5 \pm 1.12^{\mathrm{bc}}$ & $12 \pm 2.82^{\mathrm{d}}$ & $4.5 \pm 1.36^{\mathrm{c}}$ & $5.5 \pm 1.53^{c}$ & $6 \pm 1.41^{\mathrm{c}}$ & $5.5 \pm 1.12^{c}$ & $4 \pm 1.82^{\mathrm{bc}}$ & $5.5 \pm 1.53^{c}$ \\
\hline $\begin{array}{l}\text { Unwinding } \\
\text { time (min) }\end{array}$ & $14.51 \pm 0.78^{\mathrm{e}}$ & $14.85 \pm 0.65^{\mathrm{e}}$ & $8.35 \pm 0.75^{\mathrm{d}}$ & $6.75 \pm 0.61^{\mathrm{c}}$ & $5.33 \pm 0.33^{b}$ & $8.15 \pm 0.5^{\mathrm{d}}$ & $4.2 \pm 0.05^{\mathrm{a}}$ & $6 \pm 0.43^{\mathrm{bc}}$ & $3.75 \pm 0.25^{\mathrm{a}}$ & $4.03 \pm 0.18^{\mathrm{a}}$ \\
\hline $\begin{array}{l}\text { Thickness } \\
\text { muscle rolls } \\
\text { (cm) }\end{array}$ & $1.25 \pm 0.07^{\mathrm{def}}$ & $1.95 \pm 0.14^{\mathrm{g}}$ & $1.32 \pm 0.03^{\mathrm{ef}}$ & $1.41 \pm 0.02^{\mathrm{f}}$ & $0.74 \pm 0.04^{\mathrm{a}}$ & $1.06 \pm 0.05^{\mathrm{bcd}}$ & $1.08 \pm 0.12^{\mathrm{bc}}$ & $0.92 \pm 0.1^{\mathrm{ab}}$ & $1.32 \pm 0.1^{\mathrm{def}}$ & $1.14 \pm 0.21^{\mathrm{def}}$ \\
\hline \multirow[t]{2}{*}{$\begin{array}{l}\text { Brine } \\
\text { penetration } \\
\text { time (min) }\end{array}$} & $25 \pm 3^{\text {cd }}$ & $27 \pm 7^{\text {cd }}$ & $30 \pm 1.4^{\mathrm{e}}$ & $28 \pm 1.5^{\text {de }}$ & $28 \pm 1.9^{\mathrm{de}}$ & $21 \pm 1.5^{\mathrm{bc}}$ & $15 \pm 2^{\mathrm{a}}$ & $17 \pm 2.6^{\mathrm{ab}}$ & $29 \pm 4.24^{\text {de }}$ & $25 \pm 3^{\text {cd }}$ \\
\hline & \multicolumn{10}{|c|}{ Successive rolling (innovation) } \\
\hline $\begin{array}{c}\text { Weight of } \\
\text { waste from } \\
\text { unwinding (g) }\end{array}$ & $1.5 \pm 0.7^{\mathrm{ab}}$ & $3 \pm 1.41^{\mathrm{b}}$ & $1.5 \pm 0.12^{\mathrm{ab}}$ & $1 \pm 0.41^{\mathrm{a}}$ & $2.5 \pm 0.7^{\mathrm{b}}$ & $7 \pm 1.0^{\mathrm{d}}$ & $2.5 \pm 0.7^{\mathrm{b}}$ & $1.5 \pm 0.12^{\mathrm{ab}}$ & $4.5 \pm 0.7^{\mathrm{c}}$ & $1 \pm 0.41^{\mathrm{a}}$ \\
\hline $\begin{array}{l}\text { Unwinding } \\
\text { time (min) }\end{array}$ & $5.88 \pm 0.2^{f}$ & $5.58 \pm 0.21^{f}$ & $3.25 \pm 0.21^{\mathrm{ab}}$ & $5.08 \pm 0.23^{\mathrm{e}}$ & $3.11 \pm 0.21^{\mathrm{a}}$ & $4.5 \pm 0.61^{\mathrm{d}}$ & $3.71 \pm 0.31^{\mathrm{bc}}$ & $4.45 \pm 0.41^{\mathrm{d}}$ & $3.16 \pm 0.15^{\mathrm{ab}}$ & $4.18 \pm 0.38^{\mathrm{cd}}$ \\
\hline $\begin{array}{l}\text { Thickness } \\
\text { muscle rolls } \\
\text { (cm) }\end{array}$ & $1.98 \pm 0.44^{\mathrm{abc}}$ & $1.93 \pm 0.09^{\mathrm{abc}}$ & $1.8 \pm 0.1^{\mathrm{abc}}$ & $1.68 \pm 0.18^{\mathrm{a}}$ & $2.3 \pm 0.28^{c}$ & $1.87 \pm 0.03^{\mathrm{abc}}$ & $=1.75 \pm 0.21^{\mathrm{ab}}$ & $1.6 \pm 0.28^{\mathrm{a}}$ & $2.12 \pm 0.53^{\mathrm{abc}}$ & $2.14 \pm 0.22^{\mathrm{bc}}$ \\
\hline $\begin{array}{c}\text { Brine } \\
\text { penetration } \\
\text { time (min) }\end{array}$ & $45 \pm 1.9^{\mathrm{b}}$ & $32 \pm 1.5^{\mathrm{a}}$ & $58 \pm 1.8^{\mathrm{c}}$ & $51 \pm 1.4^{\mathrm{bc}}$ & $40 \pm 13^{\mathrm{a}}$ & $47 \pm 9^{b}$ & $44 \pm 1.7^{\mathrm{b}}$ & $32 \pm 1.1^{\mathrm{a}}$ & $57 \pm 1.6^{c}$ & $71 \pm 1.5^{\mathrm{d}}$ \\
\hline
\end{tabular}

N.B: Values with the same letters do not differ significantly at the probability threshold $(\mathrm{p}<0.05)$.

\subsection{Unwinding $15 \mathrm{~cm} \times 5 \mathrm{~cm} \times 5 \mathrm{~cm}$}

Unwinding $15 \mathrm{~cm} \times 5 \mathrm{~cm} \times 5 \mathrm{~cm}$ was an unwinding technique used particularly in the region of Adamaoua (Cameroon), whose quality in view of Table 1 and Table 2 has improved during aging. It was a technique applied on muscles about $15 \mathrm{~cm} \times 5 \mathrm{~cm} \times 5 \mathrm{~cm}$. It facilitated the seasoning operation as well as the sale of the product. These results in Table 2 corroborated those obtained by [14], who estimated between 25 to 38 min per $\mathrm{kg}$ of fresh meat unwound. The duration of unwinding decreased when the meat aged.

\subsection{Implementation of an Innovative Unwinding Technique by Successive Rolling}

Successive rolling is a method of unwinding of meat thought and put in experimentation to minimize the hardness of unwinding. It aims, was to reduce the arduousness, the time of the operation and the risks of scarification. This technique consisted of opening a muscle in both directions (from right to left then from left to right) in lamella form until the lowest or desired thickness was obtained. The successive rolling, differed significantly $(\mathrm{p}<0.05)$ from the two others unwinding modes (along the muscle and the $15 \mathrm{~cm} \times 5 \mathrm{~cm} \times 5 \mathrm{~cm}$ ) in terms of lasting (Table 2). The unwinding time of $500 \mathrm{~g}$ of meat went from $15.61 \pm 0.57 \mathrm{~min}$ to $5.88 \pm 0.2$ min for the round and from $14.85 \pm 0.65 \mathrm{~min}$ to $5.58 \pm$ $0.21 \mathrm{~min}$ for the thick rib in rigor-mortis state. After an aging of $96 \mathrm{~h}$ at $4 \pm 2{ }^{\circ} \mathrm{C}$, this time failed to $3.16 \pm 0.15$ min for the round and $2.48 \pm 0.38$ min for the thick rib. It appeared that, successive rolling has several advantages:

It allowed to unwind about three times faster than the previous techniques;

*It was recommended on any type of muscle, long or short, big or small and whatever the thickness of the muscle;

*It significantly reduced the risk of scarifications of fingers of the unwinder. 
(DAlong the muscle $\boldsymbol{\nabla} 15 \mathrm{~cm} \times 5 \mathrm{~cm} \times 5 \mathrm{~cm} \boldsymbol{\nabla}$ Successive rolling

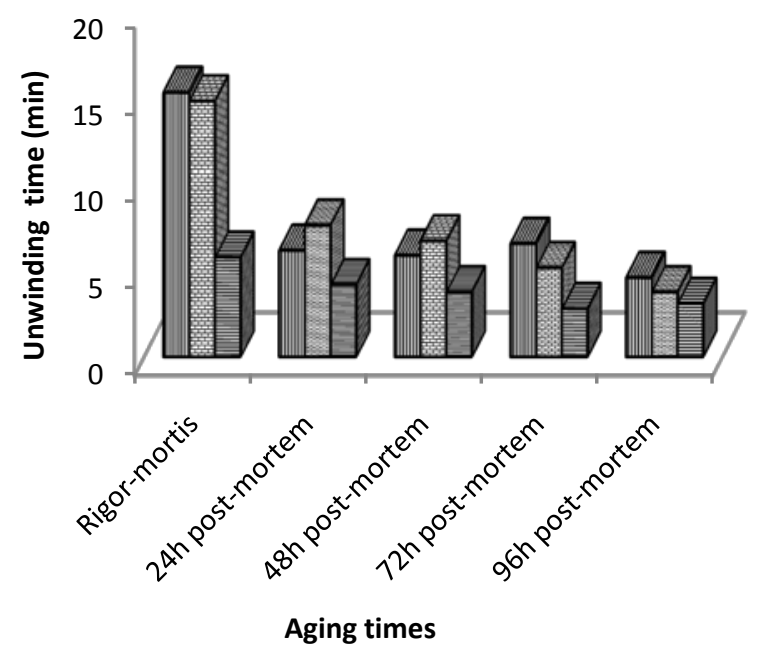

Figure 2. Lasting of different unwinding modes according to different aging states

In addition, the Figure 2 showed that the muscle must be aged for at least $96 \mathrm{~h}$ at $4 \pm 2{ }^{\circ} \mathrm{C}$, because overall there is a weakening of the myofibrillar structure. Myofibrils are increasingly weakened as they aged in cold, thus considerably reducing the hardness and the unwinding time.

\subsection{Seasoning Penetration Time}

Seasoning the dried meat lasted an average of 2 to 4 minutes. This result was similar to that of [15]. On the other hand, the penetration time was very high, it was between 15 and $30 \mathrm{~min}$ for the meat sliced resulting from unwinding along the muscle and unwinding $15 \mathrm{~cm} \times 5 \mathrm{~cm} \times 5 \mathrm{~cm}$ and from 20 to $35 \mathrm{~min}$ for those resulting from successive rolling. The penetration time of seasoning would increase depending on the state aging and the type of unwinding. The physicochemical mechanisms that contributed to this, have not been elucidated yet.

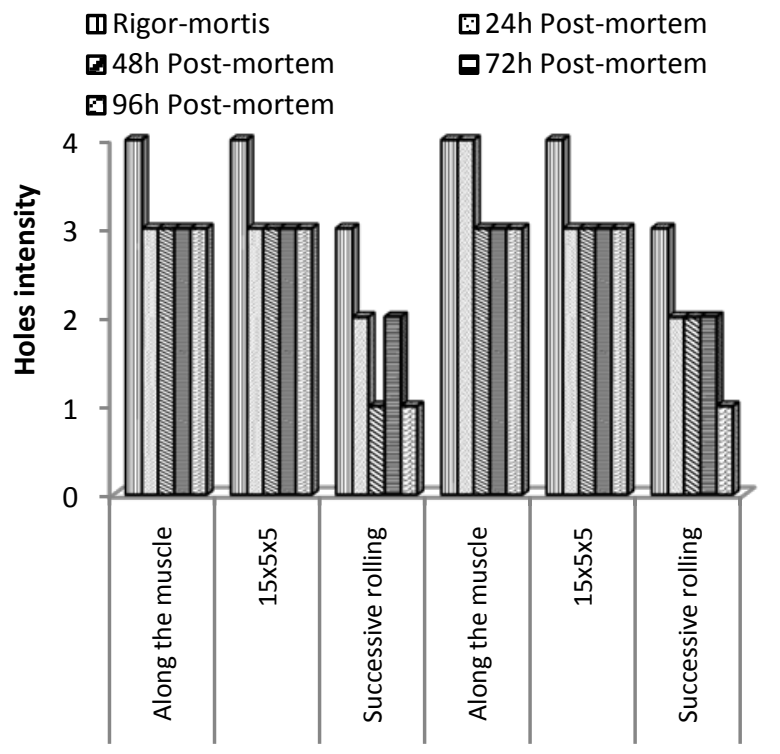

Rolling mode/Muscles
From the Figure 3, it noticed that, the intensity of holes was very low in successive rolling and decreased when the meat went into aging.

\section{Conclusion}

This work highlighted the need to reduce the hardness and the lasting of unwinding process. It appeared that, it was possible to reduce the hardness and the duration of unwinding by aging the meat and by using successive rolling as unwinding technique. Preservation of meat for at least 24 hours at $4 \pm 2{ }^{\circ} \mathrm{C}$ improved the firmness and up to $96 \mathrm{~h}$ facilitated all the types of unwinding. The successive rolling, was an innovation which fit with all muscles and significantly reduced the risk of scarification of fingers and will be introduced to the artisanal process for all the advantages stated above.

\section{References}

[1] Cameroon Food Processing. 2008. Marketing study of kilish in Cameroon.

[2] Ndjouenkeu R, Ngah Esther, Ndih A.C \& Cerdan C. 2001. The production of kilishi in Ngaoundéré (North Cameroon): technical characteristics, organization and opportunities for innovation, pp. 14-27.

[3] AFNOR, 1982. Collection of French standards for products derived from fruits and vegetables, fruit juice, 1st edition. Published by AFNOR, Paris (France).

[4] Dransfieed E., 1994. Optimization of tenderisation aging and tenderness. Meat saw.36, 105-121.

[5] Maltin, C., Balcerzak, D., Tilley, R., \& Delday, M., 2003. Determinants of Meat Quality: Tenderness. Proceeding of the Nutrition Society. 62: 337-347.

[6] Marsh B.B. \& Leet N .G., 1966. Studies in meat tenderness, .the effect of cold sortening on tenderness. J.F. Sci, 31, 450-459.

[7] Dransfieed, E., Lokyer D.K. \& Prabhakaran P., 1986. Change in extentensibility of raw beef muscle during storage. Meat Sci .16, 127-142.

[8] Kalilou, S. \& Zakhia, N, 1997. Hand-made kilishi in Niger: optimization of the process and improvement of the quality of the product. In Drying High Water Content Products in Francophone Africa, 21-24 April 1997, CTA / ABAC GERES / TPA, pp.12

[9] Kalilou, S., 1997. La fabrication artisanale peut mieux faire... B14 séchage des produits alimentaires: viande séchée. Bulletin du réseau TPA n¹4, 57-60.

[10] Penny I.F., 1985. The enzymology of conditionning development in: relationship between early post mortem $\mathrm{pH}$ and the tenderisation of beef muscle .O'halloran GR Troy D J and Buckl

[11] Ouali A., 1990. The maturation of meat. Biological and technological factors of variation. Meat and meat products, vol. 11, PP.290.

[12] Taylor, R.G., Geesink G.H., Thompson.F., Koohmaraie M. and Goll D.E. (1995). The $\mathrm{z}$ disk responsible for post mortem. Animal Science 73 (5), 1351-1367.

[13] CIV, 2004. Organoleptic qualities of beef Scientific basis for good culinary use.

[14] Kalilou, S., Collignan A. and Zakhia N., 1998. Optimizing the traditional processing of beef into kilishi. Meat science $50 \mathrm{~N}^{\circ} 1$, 21-32.

[15] Yacouba, 2009. Analysis of traditional techniques of meat processing in Kilichi in the urban district of Madaoua (Rep. of Niger), graduation thesis.

Figure 3. Intensity of holes according to unwinding modes 